\title{
Silićevo supostavljanje suprotstavljenih pojmova Silić, Josip. 2019. Dihotomije. Izabrane rasprave. Zagreb: Disput.
}

U veljači 2019. godine u Disputovu izdanju objavljena je knjiga Dihotomije. Izabrane rasprave Josipa Silića. Knjigu je uredio izvanredni profesor Ivan Marković, predstojnik Katedre za hrvatski standardni jezik zagrebačkoga Filozofskog fakulteta. Rasprave sažimlju 55 godina Silićeva obimnoga djelovanja na području jezikoslovlja. Kako i sâm urednik navodi u predgovoru, Silić »nije mario za uknjiživanje svojih radova«. Spomenimo naslove tek nekoliko knjiga koje je Silić za života objavio, a koje upućuju na širok dijapazon tema kojima se bavio: Pravopisni priručnik hrvatskoga ili srpskoga jezika (s Vladimirom Anićem) 1986. g., Hrvatski računalni pravopis: Gramatičko-pravopisni računalni vodič: Spelling-checker (sa Slavenom Batnožićem i Brankom Ranilovićem) 1996. g., Pravopis hrvatskogajezika (s Vladimirom Anićem) 2001. g., Gramatika hrvatskoga jezika za gimnazije i visoka učilišta (s Ivom Pranjkovićem) 2005. g., Funkcionalni stilovi hrvatskoga jezika 2006. godine. Ipak postojala je potreba da se jednom knjigom obuhvati ostatak nemaloga broja radova. Dobili smo rasprave okupljene na više od 700 stranica koje se tiču odnosa Sustava i standarda, Razina i jedinica, Fonologije i ortografije, Morfologije i sintakse, Teksta i reda riječi, Leksika i češnjaka te Jezika i računala. Urednik se naime potrudio da i naslovi temata u knjizi budu označeni dihotomijama. Silićevim radovima prethodi Markovićev predgovor Što je Silić hrvatskoj filologiji?, ljetopis i bibliografija Josipa Silića. U predgovoru Marković uvodi u Silićev stil akademskoga pisma, za koji kaže da nema »sočnih eskapada, neće šarmirati na prvu loptu, na Silića se treba naviknuti«. Objašnjava nadalje Silićevu strukturalističku teorijsku podlogu, doprinos na svim jezičnim razinama, u ortografiji i dijalektici, funkcionalnoj stilistici i na kraju računalnome pravopisu, što bi moglo biti začudno nekomu čitatelju namjerniku. Putovanje kroz Silićeve radove završava se Kazalom imena te Bilješkom o priređivaču.

Za prvu je tematsku cjelinu, Sustav i standard, ujedno i najopširniju u cijeloj knjizi, bitno napomenuti da se navedena dva pojma uvijek nalaze u dijalektičkom odnosu u Silićevim raspravama, što znači da jedan nikad ne isključuje drugoga. Već se u prvome dijelu knjige može osjetiti da su Silićeve rasprave snažno obilježene utjecajem de Saussurea pa i Eugenia Coseriua, čijega je prijevoda knjige Teorija jezika i opća lingvistika Silić urednik. Prve su dvije rasprave posvećene uvidima o nekim obilježjima razgovornoga stila i jezika diskusija. Zatim se nastavlja raspravom o pravilnostima, odnosno nepravilnostima jezične upotrebe. Posebno je zanimljivo to što Silić već 1987. postavlja tezu da uzor ne smijemo tražiti ni u jednom funkcionalnom stilu posebno, nego u svim funkcionalnim stilovima zajedno. Kada govori o varijantama, Silić supostavlja pojmove norme i sistema. Promišljanje o varijantama pomoći će i kada se bude raspravljalo o sinonimima, istoznačnicama i istovrijednicama. Svoj obol dao je i u raspravama o upotrebi korpusa književnih djela u politici normiranja. Njegov je zaključak tada bio da se korpus ne može odabrati 
dok se ne raščiste odnosi književnoga jezika i funkcionalnih stilova. Razlikovanje književnoga jezika i jezika književnosti očito je i u naslovu rasprave na njemačkome Die (kroatische) Literatursprache und die Sprache der (kroatischen) Literatur. Kada piše o funkcionalnim stilovima, Silić u razlici standardnoga jezika i njegovih funkcionalnih stilova nagoviješta njihov blizak odnos zaključkom da nesputan razvoj stilova omogućuje nesputan razvoj standardnoga jezika. Ono što odvaja sustav i standard jesu lingvističke, odnosno sociolingvističke zakonitosti. Po sociolingvističkim zakonitostima Silić određuje odnos standarda i narječja. U istoj raspravi donosi i zanimljivo određenje hrvatskih narječja kao triju različitih jezika kao sustava, ali napominje da se ona mogu promatrati i kao narječja. S obzirom na to da narječja promatra kao sustave, smatra da dijalektizmima u hrvatskome standardu možemo označiti samo štokavizme. Odnosu između hrvatskoga i srpskoga jezika Silić dakako pristupa iz vizure dihotomije sustav i standard. Ta su dva jezika, kaže Silić, kao sustavi isti, a kao standardi različiti. U raspravi Crnogorski jezik polemizira s knjigom Dalibora Brozovića Standardni jezik naglašavajući kako je Brozovićeva pogreška što standardne jezike promatra kao sisteme pa ne uočava potencijal u tome da hrvatski, crnogorski ili srpski jezik budu samostalni i da se samostalno normiraju. Nastavljajući se na razlikovanje funkcionalnih stilova i standardnoga jezika, donosi i nekoliko novih zaključaka među kojima izdvajamo onaj da jezik književno-umjetničkoga djela ne smatramo jednom od funkcija standardnoga jezika. Najopširnije se poglavlje završava rekonstrukcijama jezika Gorskoga vijenca Petra Petrovića Njegoša i opisom stila Krunoslava Pranjića.

Razine i jedinice naslov je drugoga poglavlja knjige. U kronološki su prvoj raspravi opisane i oprimjerene fonostilistička, morfonostilistička, sintaktostilistička i semantostilistička razina. Primjećujemo kako je Silić započeo opisom stilističkoga plana jezika, a tek kasnije slijede rasprave o jezičnim disciplinama i njihovim jedinicama. Već šezdesetih godina on ima na umu morfonostilističku razinu, a na jedinici će morfonem i kasnije inzistirati, kako i u predgovoru napominje urednik Ivan Marković. Daje svoj prilog raspravi o samoznačnim i suznačnim riječima napominjući kako se pri klasifikaciji treba voditi računa o gramatičkoj, ali i o komunikacijskoj funkciji rečenice. Kada piše o vezi gramatičkoga i leksičkoga značenja, Silić uvodi i razlikovanje osnove i korijena. Jezične discipline i njihove jedinice ponovno aktualizira na skupu Riječki filološki dani 2008. kada govori da se jezične jedinice konkretiziraju u svojim međudisciplinama. Navodi i da iznad tekstema nema međudiscipline pa se te jedinice konkretiziraju u tekstologiji kada gramatika prepušta ulogu komunikaciji. Također naglašava da je vezno sredstvo na razini teksta konektor. U sljedećoj raspravi Silić nas upoznaje s još jednom međudisciplinom - tekstosintaktologijom, čija je jedinica tekstosintaktem zapravo varijantna rečenica. Iako se hrvatski jezik klasifikacijski ubraja u sintetičke jezike, Silić u raspravi Oprekejezika kao sistema predlaže definiranje hrvatskoga kao sintetičko-analitičkoga jezika. Prefiksacijom dolazimo do svršenosti radnje, a predpozicionalizacijom do određenih pa- 
deža. U toj istoj raspravi Silić pravi razliku između rečenice kao obavijesne i rečenice kao gramatičke jedinice.

Treća je tematska cjelina Fonologija i ortografija obilježena dihotomijom sinkronija : dijakronija ili odnosom fonološkoga proučavanja s pomoću povijesti i promatranja zatečenoga stanja. U raspravi Fonemska distribucija i sekundarno a u suvremenom hrvatskosrpskom književnom jeziku Silić se odlučuje isključiti povijest jer takva analiza daje mnogo čistije rezultate. Prema tome u narednim raspravama donosi nekoliko teza koje su važne za daljnja ortoepska, ortografska i fonološka istraživanja. Primjerice zaključuje da intonacijsko oblikovanje ne može biti postignuto bez poznavanja distribucije fonema, uvjeta koji vladaju na granici morfema i riječi. Godine 1976. u članku Ortoepija/ortografija i morfematska struktura jezika donosi definiciju, doduše omeđenu zagradama, morfonematike ili morfonologije: jezična disciplina koja proučava načine iskorištavanja fonoloških opreka radi izražavanja morfoloških razlika. Tu je definiciju preuzeo od O. S. Ahmanove. U istoj raspravi piše da bi miješanje ortografije u unutrašnje stvari jezika bilo nedopustivo. Zanimljivo je da uvijek ostavlja mjesta za potenciju stilistički markiranih oblika. Čak i kada se raspravlja o ortografiji i pravopisnoj normi, postavlja retoričko pitanje Je li norma samo realizacija ili i potencija? Kroz nekoliko se rasprava kao ovlaš spominje i pitanje polusloženica za koje u konačnici smatra da smo ih sami stvorili eda bi se njima teoretski bavili. U ovome se poglavlju nalaze i rasprave u kojima polemizira s Babićevim rješenjima iz Tvorbe riječi u hrvatskom književnom jeziku (Nacrt za gramatiku) te ona posvećena doprinosu Ljudevita Jonkea u kojoj ističe njegovu borbu za zaštitu identiteta hrvatskoga književnog jezika. Pišući o interpunkciji, supostavlja melodijsko i semantičko načelo interpunkcije, pri čemu prednost daje semantičkoj interpunkciji koja bi imala pomoć u melodijskoj. Cjelina završava člankom Nepostojano (poluglasničko) a u imenicama hrvatskoga jezika objavljenom u broju Nove Croatice koja je bila posvećena Stjepanu Damjanoviću. Kako je otvorena, tako i završava, postavljanjem razlike stanja i povijesti, i dodaje da povijest ne mijenja jezik, nego ga samo iskazuje današnjim sredstvima.

U četvrtom poglavlju Morfologija i sintaksa donosi bitan zaključak u raspravi o ulozi gramatičkih morfema - kategorija padeža ima gramatički, a kategorija broja gramatičko-leksički karakter, što znači da kategorija padeža čini paradigmatsku, a kategorija broja sintagmatsku os kategorizacije. Raspravom Sustav preteritalnih glagolskih vremena nekad i danas donosi pregled promjena, ali upućuje na daljnja istraživanja pojava o kojima je riječ. Nakon što je donio pregled stranih pogleda na segmentaciju internacionalizama, predlaže jedinstvenu metodu segmentacije: $\operatorname{organizac(ij//i)(Ø//on)(a)+ni.~Takvim~se~segmentiranjem,~vjeruje~Silić,~rastereću-~}$ je sufiks elemenata koji zapravo pripadaju osnovi. Koliko Silić razmišlja unaprijed, vidljivo je iz zaključne rečenice iste rasprave u kojoj nagovješćuje da njegov način formalizacije može pomoći i računalnoj obradi derivatoloških podataka. Kada govori o ustrojstvu glagolske osnove, Silić na umu ima da se jezikoslovci uglavnom služe infinitivnom i prezentskom osnovom pri objašnjavanju. On nastoji dokazati 
da se svaki oblik tvori od vlastite osnove te ulaže ozbiljan metodološki prigovor na zahtjev da se svi glagoli moraju izvoditi iz infinitivne i prezentske osnove. Još jedna zanimljiva teza ide u prilog već prethodno spomenutoj tezi da hrvatski jezik nije u potpunosti sintetički jezik. Naime analizirajući aktualizator jedan, Silić pokazuje da se može govoriti o članu u hrvatskome jeziku. Sljedeća česta pogreška na koju upozorava jest neovjeravanje razlike između rečenice i iskaza. Rečenica dakako pripada gramatičkome (potencijalnom), a iskaz komunikativnome (aktualnom) planu. $\mathrm{Na}$ razini iskaza valentnost se dokida pa se Silić s pravom pita kojem planu pripada valentnost: gramatičkom ili komunikativnom. Puno je određeniji kada piše o kategoriji neodređenosti/određenosti. Za razliku od većine gramatika Silić smatra da kategorija treba biti jedna od lingvističkih univerzalija te je označuje sintaktičkom morfologiziranom kategorijom.

Tekst i red riječi naziv je pete tematske cjeline koja obuhvaća rasprave vezane uz promatranje rečenice kao gramatičke i komunikacijske jedinice, konektore, vezanje rečenica u tekst, raspravljanje kao tip vezanoga teksta te obiluje metodološkim napomenama i savjetima kao i zanimljivim tezama o tome što su stilogeni elementi u tekstu. Već u raspravi O jednoj mogućnosti organiziranja vezanog teksta donosi svoju podjelu elemenata koji se vežu u tekst na komunikative i tematske elemente koji čine tematski snop. Dalje slijede njegove misli o raspravljanju kao tipu vezanoga teksta. Osim o razlici između rečenice i iskaza govori i o razlici između statičke i dinamičke rečenice pri čemu bi statička bila ona na gramatičkoj, a dinamička na komunikativnoj razini. Dinamička se rečenica sastoji od teme i reme, ali napominje da to ne podrazumijeva da je tema ono što je dato, a rema ono što je novo. Što se tiče reda riječi, smatra da ne možemo govoriti o stilogenosti inverzije a da ne uključimo kontekst. Piše da su elementi maksimalno uvjetovani kontekstom minimalno stilogeni. Zaključuje da komponente osnovnoga semantičko-gramatičkog reda mogu biti permutirane i nepermutirane pri čemu se potonje realiziraju logičkim akcentom, a prve preponiranjem, postponiranjem, distaktiranjem, dislociranjem i cirkumponiranjem. O dihotomiji rečenice kao gramatičke i komunikacijske jedinice završno govori kako prva nije, a druga jest smislena, odnosno da rečenica svoj smisao dobiva tek izvan sebe. Donosi još razliku između finitivnih i inkoativnih rečenica te linearne i paralelne veze među rečenicama.

Na kraju dolazimo do dvaju poglavlja koja su opsegom manja od prethodnih, ali nisu manje bitna po svojim zaključcima i istraživanjima. Šesto je poglavlje nazvano Leksik i češnjak prema čemu se može zaključiti da teme postaju semantički obojene. Da bi mogao pisati o idionimima u jeziku, Silić je morao objasniti razliku između koinonima i idionima, odnosno općih imenica i vlastitih imena. Za idionime misli da su nositelji i čuvari identiteta te da bi bilo poželjno da ostaju što više slični sebi. Pita se i zašto pišemo image kada takve riječi nemaju nikakve veze s idionimima. O dihotomiji designativno : konotativno piše kroz istraživanje pripisivanja negativnih značenja poput pejorativnosti riječima u rječnicima. Silić je stava da etiketiranje konotacije ne bi smjelo ulaziti u rječnike zbog drugačijega odnosa 
prema konotaciji sastavljača rječnika i onih koji se njime služe. U raspravi Leksik $i$ norma nailazimo na razlikovanje dubleta, sinonima i varijanata. U posljednjem se poglavlju Jezik i računalo vraćamo dihotomiji s početka i tako nastaje zaokružena cjelina. Kada piše o stvaranju računalnoga pravopisa i dostignućima u hrvatskoj računalnoj lingvistici, polazi od razlikovanja jezika kao sustava i jezika kao standarda. Namjera je bila opisati komunikacijsku realnost hrvatskoga standardnog jezika u svim njegovim funkcionalnim stilovima. Za to nije mogla poslužiti Gramatika hrvatskoga jezika jer je naravno trebao opis za stvaranje, dakle hrvatski jezik koji se temelji na sustavu. Trud je rezultirao stvaranjem hrvatske inačice spelling-checkera. Taj je sustav nezainteresiran za eventualnu stilsku markiranost riječi poput majaka jer je u hrvatskom jeziku kao sustavu taj oblik moguć. Kao što i Marković navodi u predgovoru, jedna je od namjera bila i popraviti odnos korisnika prema hrvatskome standardnom jeziku. Znajući koliko se ljudi svakodnevno koristi spelling-checkerom tipkajući, a da i ne znaju koliko je truda uloženo u stvaranje tog sustava, barem je jedna od namjera ispunjena.

Knjiga Dihotomije. Izabrane rasprave zbog domišljatosti urednika u naslovljavanju te pedantnosti i minucioznosti u odabiru rasprava koje će činiti pojedine tematske cjeline pohvala je djelu Josipa Silića, a zbog detaljno napisanoga predgovora i njegovoj osobi. Zbog svoje obimnosti neće se čitati u dahu, no knjiga na to uostalom ne pretendira. Urednik nas, kao što sam već napomenula, upozorava da se na Silićev stil pisanja treba naviknuti. Međutim knjiga je retorički i metodološki organizirana tako da se i ne osjeti prolaženje kroz proces navikavanja. Tomu naravno pomaže i Silićeva tekstna organizacija raspravā. Argumentacija je u svakoj raspravi organizirana tako da se grana prema karakterističnim početnim dihotomijama. Čitatelju je prema tome lakše percipirati što se donosi kao teza i zaključak. Izlišno je govoriti o značaju Josipa Silića za hrvatsko jezikoslovlje, ali ova je knjiga samo jedan od dokaza da je svojim radom ostavio velik trag na svim jezičnim razinama, disciplinama i znanostima koje su vezane uz jezik. Komu preporučiti ovu knjigu? Naravno jezikoslovcima i lingvistima, jezičnim entuzijastima i programerima, stilističarima i pragmalingvistima, standardolozima i puristima, pravopiždžijama i logičarima, političarima i kulturnjacima, komunikolozima i retoričarima. Svaka rasprava gore navedenima može poslužiti kao potencija za daljnja promišljanja $i$ istraživanja, a profesorima i studentima kao metodološki priručnik. 